\title{
The Fusability of Erythrocytes as a Method for Evaluating the Instability of Their Membranes
}

\author{
Yury A. Sheremet'ev", Aleksandra N. Popovicheva, Methun M. Rogozin, Gregory Y. Levin \\ Nizhny Novgorod Scientific Research Institute of Traumatology and Ortopedics, Nizhny Novgorod, Russia \\ Email: *ya.sher@rambler.ru
}

Received December 7, 2012; revised January 10, 2013; accepted January 17, 2013

Copyright (C) 2013 Yury A. Sheremet'ev et al. This is an open access article distributed under the Creative Commons Attribution License, which permits unrestricted use, distribution, and reproduction in any medium, provided the original work is properly cited.

\begin{abstract}
A novel approach to the study of erythrocytes instability based on assessment fusability of their plasma membrane is presented. The fusability of erythrocytes normal blood, stored for 7 days at $4^{\circ} \mathrm{C}$, and type 2 patients with diabetes were studied. Human erythrocytes were fused by incubation with $\mathrm{La}^{3+}$ at final concentrations from 50 to $200 \mu \mathrm{M}$. Erythrocytes aggregates were incubated at $37^{\circ} \mathrm{C}$ for $120 \mathrm{~min}$. The fusability of erythrocytes was evaluated using a light microscope. It was shown that $\mathrm{La}^{3+}$ induced extensive fusion of erythrocytes after 7 days of blood storage and erythrocytes of patients with diabetes. Incubation of normal erythrocytes at $37^{\circ} \mathrm{C}$ for $120 \mathrm{~min}$ does not induce cell fusion.
\end{abstract}

Keywords: Erythrocytes; Fusability; Membrane Instability; $\mathrm{La}^{3+}$

\section{Introduction}

Membrane fusion is ubiquitous cellular process mediating such phenomena as fertilization, exocytosis, phagocytosis, etc. [1]. Fusion can be induced by chemical agents [2]. We have previously shown that $\mathrm{La}^{3+}$ induced extensive fusion of erythrocytes with an altered ATP content [3].

It is known that the lanthanides have an extremely high affinity for phosphatidylserine [4]. It is shown that $\mathrm{La}^{3+}$ at low concentrations induces fusion phosphatidylserine vesicles [5]. Exposure of phosphatidylserine on the surface of lipid-symmetric erythrocytes may be responsible for their enhanced fusion [6]. Phosphatidylserine externalization leads to erythrocyte disintegration, or, in the presence of macrophages, to macrophage ingestion of dying erythrocytes $[7,8]$. It has been shown that chronic inflammation [9] and heart shock [10] greatly increase the frequency of cell fusion.

When whole blood is stored in a preservative medium, there may be morphological, biochemical, and metabolic change in the red blood cells [11].

Diabetes mellitus is the most prevalent metabolic disease and represents a serious clinical and public health problem. Increased oxidative stress and decreased life span of erythrocytes are reported in patients with type 2 diabetes. A positive correlation between lipoperoxidation and phosphatidylserine externalization in erythrocytes

${ }^{*}$ Corresponding author. of patients with diabetes was found [12].

In the present study, we investigated the influence of $\mathrm{La}^{3+}$ on the fusion of erythrocytes blood storage and erythrocytes of patients with diabetes.

\section{Methods and Materials}

This study included 8 healthy volunteers and 5 type 2 patients with diabetes. Blood from all study subjects was obtained by venous puncture in vacuum tubes containing $3.2 \%$ sodium citrate (in a ratio 9:1) as an anticoagulant. Each sample was centrifuged $(3000 \times \mathrm{g}, 20 \mathrm{~min})$, and the

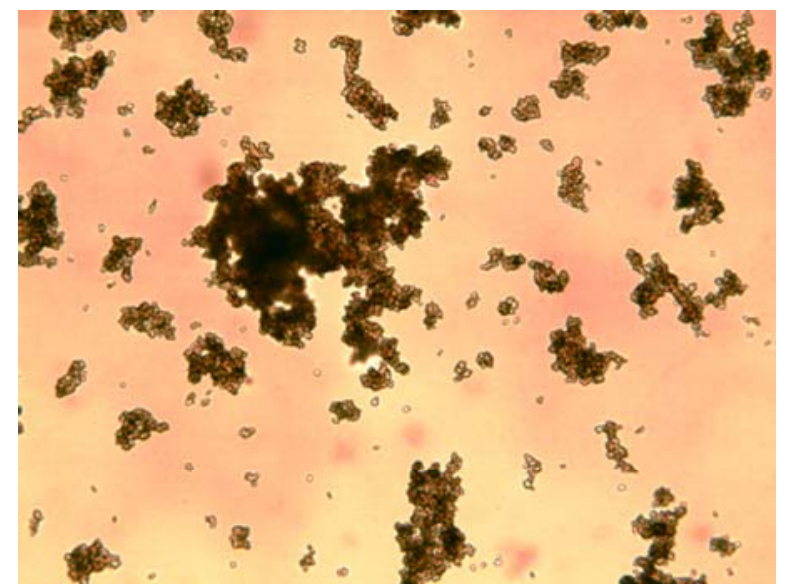

Figure 1. Influence of $\mathrm{La}^{3+}(150 \mu \mathrm{M})$ on fusion of normal of human erythrocytes. Incubation for $120 \mathrm{~min}$ at $37^{\circ} \mathrm{C} \times 100$. 
plasma and white cells were carefully removed by aspiration to avoid loss of erythrocytes. Erythrocytes were washed three times with a physiological solution (150 $\mathrm{mM}$ ). Then $0.05 \mathrm{ml}$ of washed red blood cells was resuspended in $10 \mathrm{ml}$ of $10 \mathrm{mM}$ Tris- $\mathrm{HCl}(\mathrm{pH} \mathrm{7.4)}$ containing $150 \mathrm{mM} \mathrm{NaCl}$. To $0.9 \mathrm{ml}$ of the erythrocyte suspension in plastic tubes was added $0.1 \mathrm{ml}$ lanthanum ion in final concentration from 50 to $200 \mu \mathrm{M}$ and after cell aggregation incubated for $120 \mathrm{~min}$ at $37^{\circ} \mathrm{C}$. Fusion of red blood cells was studied in the day taking and after 7 day storage of whole blood healthy volunteers at $4^{\circ} \mathrm{C}$. Fusion of red blood cells was studied using light microscopy (Primo Star Carl Zeiss). Tris and $\mathrm{LaCI}_{3} \cdot 7 \mathrm{H}_{2} \mathrm{O}$ were purchased from Sigma-Aldrich (St. Louis, MO, USA).

\section{Results and Discussion}

The results show that $\mathrm{La}^{3+}$ induced aggregation of human

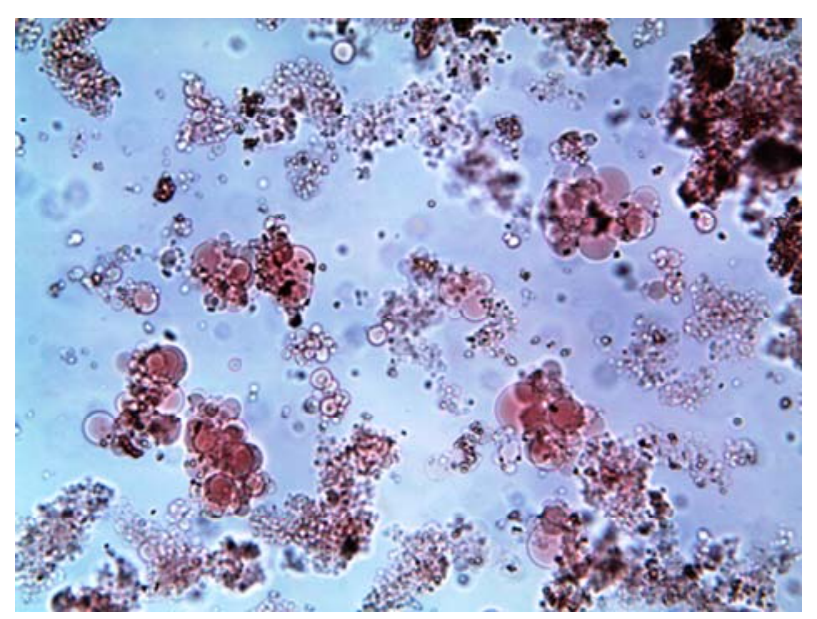

Figure 2. $\mathrm{La}^{3+}(150 \mu \mathrm{M})$-induced fusion of human erythrocytes after 7 days blood storage. Incubation for $120 \mathrm{~min}$ at $37^{\circ} \mathrm{C} \times 100$.

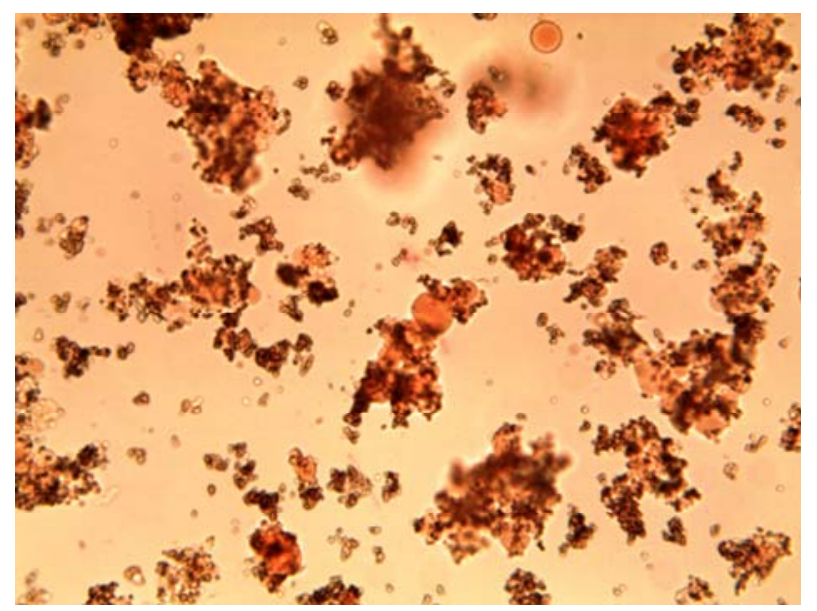

Figure 3. $\mathrm{La}^{3+}(150 \mu \mathrm{M})$-induced fusion of erythrocytes of patients with diabetes. Incubation for $120 \mathrm{~min}$ at $37^{\circ} \mathrm{C} \times$ 100. erythrocytes. Incubation of aggregates normal erythrocytes for $120 \mathrm{~min}$ at $37^{\circ} \mathrm{C}$ does not cause cell fusion (association of contents cell) (Figure 1).

Figure 2 shows that $\mathrm{La}^{3+}$ induced extensive fusion of erythrocytes after 7 days of blood storage.

Figure 3 shows that $\mathrm{La}^{3+}$ induced fusion of erythrocytes of patients with diabetes.

Our results indicate that $\mathrm{La}^{3+}$ induced fusion of erythrocytes with instability their membranes.

In conclusion, the usability in evaluating instability cell membranes provides simple and powerful tool for novel approach in investigation of erythrocytes membranes.

\section{REFERENCES}

[1] J. A. Lucy, "The Fusion of Biological Membranes," Nature, Vol. 227, No. 5260, 1970, pp. 815-817. doi: $10.1038 / 227815 \mathrm{a} 0$

[2] J. A. Lucy, "Mechanisms of Chemically Induced Cell Fusion," Membrane Fusion (Cell Surface Reviews), Vol. 5, 1978, pp. 267-304.

[3] Yu. A. Sheremet'ev and A. V. Sheremet'eva, "The Effect of Intracellular ATP Content on the $\mathrm{La}^{3+}$-Induced Aggregation and Fusion of Human Erythrocytes," Biophysics, Vol.47, No.2, 2002, pp. 288-291.

[4] Y. A. Ermakov, K. Kamarajau, K. Sengupta and S. Sukharev, "Gadolinium Ions Block Mechanosensitive Channels by Altering the Packing and Lateral Pressure of Anionic Lipids," Biophysical Journal, Vol. 98, No. 6, 2010, pp. 1018-1027. doi:10.1016/j.bpj.2009.11.044

[5] J. Bentz, O. Alford, J. Cohen and N. Duzgunes, "La ${ }^{3+}$ Induced Fusion of Phosphatidylserine Liposomes. Close Approach, Intramembrane Intermediates, and the Electrostatic Surface Potencial," Biophysical Journal, Vol. 53, No. 4, 1988, pp. 593-607.

doi:10.1016/S0006-3495(88)83138-2

[6] E. K. Tullius, P. Williamson and R. A. Schlegel, "Effect of Transbilayer Phospholipids Distribution on Erythrocyte Fusion,” Bioscience Reports, Vol. 9, No. 5, 1989, pp. 623-633. doi:10.1007/BF01119806

[7] D. Bratosin, J. Estaquier, F. Petit, D. Arnoult, B. Quatannens, J.-P. Tissier, C. Slomianny, C. Sartiaux, A. Alonso, J.-J. Huart, J. Montreuil and J. C. Amelsen, "Programmed Cell Death in Mature Erythrocytes: A Model for Investigating Death Effector Pathways Operating in the Absence of Mitochondia," Cell Death and Differentiation, Vol. 8, No. 12, 2001, pp. 1143-1156. doi:10.1038/sj.cdd.4400946

[8] K. S. Lang, P. A. Lang, C. Bauer, C. Duranton, T. Wieder, S. Huber and F. Lang, "Mechanisms of Suicidal Erythrocyte Death," Cellular Physiology and Biochemistry, Vol. 15, No. 5, 2005, pp. 195-202. doi:10.1159/000086406

[9] C. B. Johansson, S. Youssef, K. Koleckar, C. Holbrook, R. Doyonnas, S. Y. Colber, L. Steinman, F. M. Rossi and H. M. Blan, "Extensive Fusion of Haematopoietic Cells with Purkinje Neurons in Response to Chronic Inflammation," Natural Cell Biology, Vol. 10, No. 5, 2008, pp. 
575-583. doi: $10.1038 /$ ncb1720

[10] J. L. Spees, S. D. Olson, J. Ylostalo, P. J. Lynch, J. Smith, A. Perry, A. Peister, M. Y. Wang and D. J. Prockor, "Differentiation, Cell Fusion, and Nuclear Fusion during ex vivo Repair of Epithelium by Human Adult Stem Cells from Bone Marrow Stroma," Proceedings of the National Academy of Sciences USA, Vol. 100, No. 5, 2003, pp. 23397-23402. doi:10.1073/pnas.0437997100

[11] G. M. D’Amici, S. Rinalducci and L. Zolla, "Proteomic Analysis of RBC Membrane Protein Degradation during
Blood Storage," Journal of Proteome Research, Vol. 6, No. 8, 2007, pp. 3242-3255. doi:10.1021/pr070179d

[12] J. V. Calderon-Salinas, E. G. Munos-Reyes, J. F. Guerrero-Romero, M. Rodriguez-Moran, R. L. Bracho-Riquelme, M. A. Carrera-Gracia and M. A. Quintanar-Escorza, "Eryptosis and Oxidative Damage in Type 2 Diabetic Mellitus Patients with Chronic Kidney Disease," Molecular Cellular Biochemistry, Vol. 357, No. 1-2, 2011, pp. 171-179. doi:10.1007/s11010-011-0887-1 